\author{
Любий Є.В., Колій О.С. \\ Харківський національний автомобільно-дорожній університет
}

\title{
ОЦІНКА ТОЧНОСТІ СИНТЕТИЧНИХ МОДЕЛЕЙ РОЗРАХУНКУ ПАСАЖИРСЬКИХ КОРЕСПОНДЕНЦІЙ НА ПРИКЛАДІ МАЛИХ МІСТ
}

\footnotetext{
У роботі розглянуто питання щодо проведення оцінки точності результатів формування матриці пасажирських кореспонденцій з використанням гравітаційної та ентропійної моделей на прикладі малих міст в рамках інтервальної концепції моделювання потреб населення міст у пересуваннях. Основою для проведення такої оцінки є наявність фактичної матриці кореспонденцій, яка характеризує певний розрахунковий період, $\mathrm{i}$ яка отримана на основі проведення натурних спостережень за роботою громадського транспорту.

Ключові слова: матриця пасажирських кореспонденцій, малі міста, оцінка точності, синтетичні моделі, громадський транспорт, обстеження пасажиропотоків.
}

Постановка проблеми. Одним з головних питань при розробці заходів щодо підвищення ефективності функціонування громадського транспорту (ГТ) в містах $є$ формування моделі попиту на пересування пасажирів, яка представляється у вигляді квадратної матриці пасажирських кореспонденцій (МПК), в кожній клітинці якої міститься інформація про кількість фактичних або потенційних пересувань між транспортними районами (ТР). Слід відзначити, що основними підходами до формування МПК, що кардинально відрізняються за змістом і складом виконуваних робіт, є проведення натурних спостережень за роботою ГТ та використання синтетичних моделей розрахунку кореспонденцій, які мають властиві їм недоліки. Для першої групи методів це - потреба в значних трудових і часових витратах на їх реалізацію, а для другої - великі розбіжності між реальними та розрахунковими значеннями кореспонденцій. До цього також слід додати відсутність способів оцінювання якості моделювання потреб населення у пересуваннях та можливості порівняння різних МПК між собою.

Також необхідно розуміти, що для використання синтетичних моделей потрібно мати інформацію про місткості ТР з відправлення та прибуття пасажирів, яку можна отримати тільки за результатами натурних спостережень за роботою міського ГТ. Враховуючи специфіку транспортного обслуговування малих міст ГТ існує можливість збору об’єктивної інформації про потреби населення в пересуваннях обмеженою групою відповідно підготовлених обліковців, в результаті чого буде сформована фактична МПК, яка характеризуватиме відповідний розрахунковий період, та буде використана для проведення оцінки точності основних синтетичних моделей розрахунку пасажирських кореспонденцій.

Аналіз останніх досліджень. Процес формування об’єктивної та точної МПК для розглянутого періоду та об'єкту дослідження є основним завданням на етапі моделювання попиту населення на пересування ГТ. Також слід розуміти, що у відповідності до вимог нормативних документів України в галузі транспортного планування, МПК повинна бути основою моделювання роботи ГТ $[1,2]$.

Слід відзначити, що при формуванні МПК у містах основною альтернативою натурним спостереженням наразі є теоретичні методи моделювання МПК, але їх використання на прикладі малих міст можливе лише у випадку, коли існують передумови оцінки їхньої якості.

Характерною рисою існуючих теоретичних методів одержання матриці кореспонденцій $\epsilon$ те, що вони засновані на пошуках закономірностей у виборі пари «житло - робота»»), існування яких засноване на законі великих чисел і дотримання якого можливе тільки для великих, крупних i найкрупніших міст. У малих містах ці закономірності не можуть носити сталого характеру через незначний обсяг розглянутої сукупності та великої кількості кореспонденцій, що визначаються у МПК. Крім того, реалізація цих методів здебільшого вимагає серйозних трудових і матеріальних витрат, що є важливою перепоною на шляху їхньої реалізації в малих містах.

Вважається, що отримані за допомогою натурних обстежень матриці $\epsilon$ реальним відображенням потреб населення в пересуваннях на період проведення обстеження. Але результати обстежень значно втрачають свою актуальність на момент реалізації управлінських рішень, які виробляються за допомогою натурної МПК, оскільки відзначаються значним проміжком часу між початком обстеження та отриманням результатів. Звідси виходить, що для отримання МПК, яка б відповідала періоду реалізації управлінських рішень, об’єктивно необхідним $є$ використання 
теоретичних методів моделювання МПК, реальна перевірка якості яких можлива лише за умови наявності спеціальних методів оцінки точності матриць [3].

Приступаючи до аналізу існуючих моделей розрахунку матриць кореспонденцій, варто навести дуже важливу для розуміння сутності питання, що розглядається, цитату з НСМ 2000: «Мета оцінювання складається не у визначенні точної матриці кореспонденцій, а у знаходженні такої, яка достатньо близька до неї й відповідає даним інтенсивності руху» [4]. Це свідчить, що на сьогодні перед науковцями навіть і не ставиться завдання встановлення точного значення кореспонденцій у матриці, оскільки перевірити близькість розрахункової матриці до фактичної неможливо, через відсутність останньої.

В науковій та практичній літературі виділяються три основних теоретичних підходи до формування МПК: статистичний, синтетичний та ймовірнісний.

Перший підхід потребує проведення натурних обстежень пересувань $[5,6]$ і дозволяє одержати максимально достовірну інформацію про потреби міського населення у перевезеннях. Такі обстеження здебільшого є суцільними та проводяться анкетним методом. Як результат обстежень можна отримати адреси місць проживання та роботи кожної людини та маршрути руху за видами транспорту, що $є$ найбільш повною інформацією про кореспонденції та дозволяє сформувати найбільш точну матрицю пересувань [7].

Даний підхід також передбачає застосування статистичних методів розрахунку МПК, які дозволяють розповсюдити наявні величини кореспонденцій поточного або попередньо дослідженого періоду на майбутній період аналізу. До таких методів відносяться метод єдиного коефіцієнта росту, метод середніх коефіцієнтів росту, метод Фратара (Фернесса), детройтський та паризький методи [8, 9]. Згідно з цими методами екстраполяція матриці кореспонденцій на майбутній період полягає у застосуванні коефіцієнтів росту, які відображають можливу перспективну пропорційну зміну значення існуючої (відомої) кореспонденції у майбутньому.

При другому підході для одержання матриці кореспонденцій використовуються різноманітні синтетичні моделі, засновані на припущенні про схожість процесів, що відбуваються в транспортній системі міста, із законами природи $[11,12]$. Такий підхід вимагає значно менших витрат праці для формування матриці кореспонденцій, однак не дозволяє одержати результати високої точності. Для розрахунку кореспонденцій застосовуються гравітаційні, ентропійні моделі та метод проміжних можливостей. Найбільше визнання та розповсюдження в рамках даного підходу отримала гравітаційна модель $[13,14]$.

Гравітаційна модель заснована на припущенні про аналогію поведінки пасажирів при здійсненні поїздок в ТС із законом всесвітнього тяжіння, згідно з яким сила притягання двох тіл прямо пропорційна їх масі та зворотно пропорційна квадрату відстані між ними. У випадку визначення кореспонденцій тілами $€$ ТР, а їх масою - місткості по прибуттю та відправленню пасажирів $[14,15]$ :

$$
D_{i j}=k \frac{H O_{i} \cdot H P_{j}}{c_{i j}^{2}}
$$

при обмеженнях

$$
D_{i j}>0 ; \sum_{j=1}^{N_{T P}} D_{i j}=H O_{i} ; \sum_{i=1}^{N_{T P}} D_{i j}=H P_{j},
$$

де $D_{i j}$ - кореспонденція між парою ТР $i$ та $j$, пас.; $k$ - калібрувальний коефіцієнт (певна константа); $H O_{i}, H P_{j}$ - місткості ТР з відправлення та прибуття пасажирів, пас.; $c_{i j}$ - складність сполучення між районами $i$ та $j$; $N_{T P}-$ кількість ТР, од.

Розрахунок матриці кореспонденцій по даній моделі потребує проведення спеціальної ітераційної процедури, в ході якої розраховуються значення калібрувальних коефіцієнтів для кожної ітерації. Калібрування моделі здійснюється до тих пір, доки не будуть виконані умови (2).

Окрім класичного варіанту гравітаційної моделі розповсюджені іiі модифікації. Різновидом гравітаційної моделі є отриманий на її основі метод розрахунку кореспонденцій з використанням функції спротиву EVA, запропонованої Д. Лозе [16]. Даний метод побудований з огляду на три етапи 
формування кореспонденцій «Створення - Розподіл - Поділ». Основою розподілу кореспонденцій між ТР згідно $з$ даною моделлю є час пересування.

Достатньо велике розповсюдження в рамках синтетичного підходу отримала також ентропійна модель розрахунку кореспонденцій, яка заснована на припущенні про аналогію процесів, що відбуваються в транспортній системі, з термодинамічними $[8,17]$. Визначення МПК згідно з цією моделлю полягає у максимізації критерію

$$
\sum_{i=1}^{m} \sum_{i=1}^{n} D_{i j} \ln \frac{1}{D_{i j}} \rightarrow \max
$$

при обмеженнях

$$
D_{i j} \geq 0 ; \sum_{j=1}^{n} D_{i j}=H O_{i} ; \sum_{i=1}^{m} D_{i j}=H P_{j} ; \sum_{i=1}^{m} \sum_{j=1}^{n} c_{i j} D_{i j}=C_{3 a 2},
$$

де $m, n$ - кількість районів прибуття та відправлення, од.; $C_{3 a z}$ - загальні транспортні витрати при поїздках.

Вираз (3) являє собою ентропію системи, а його максимізація приводить до визначення такої МПК, яка відповідає найбільш ймовірному стану транспортної системи.

До переваг ентропійної моделі можна віднести відносно невелику трудомісткість розрахунків та зрозумілість критерію оптимізації - мінімізація витрат часу на поїздки. Серед недоліків слід виділити те, що розрахунок МПК можливий лише за умови замкнутості транспортної системи, тобто в ній не допускається введення нових чи закриття існуючих ділянок вулично-дорожньої мережі та витрати на проїзд маршрутами ГТ повинні бути незмінними. Ще одним недоліком даної моделі $\epsilon$ сумнівна схожість термодинамічних процесів з транспортними.

До синтетичних моделей розрахунку МПК також відноситься метод зустрічних можливостей, започаткований С. Стоуффером та розвинений М. Шнайдером. Ідея методу полягає в тому, що у кожного пасажира під час здійснення поїздок є можливості задовольнити свою потребу в пересуванні по мірі віддалення від пункту відправлення та чим більшу відстань він долає на своєму шляху, тим більші ці можливості. Іншими словами, розглядаються ймовірності закінчення пересування у альтернативних пунктах призначення, розташованих на шляху прямування та здатних задовольнити потребу у пересуванні. Недоліком методу зустрічних можливостей $є$ припущення про однорідність розподілу альтернативних пунктів закінчення пересувань по досліджуваній області [8].

В рамках ймовірнісного підходу особливої уваги заслуговують моделі дискретного вибору. Такі моделі засновані на теорії корисності, згідно з якою кожен пасажир обирає шлях прямування 3 деякої скінченної кількості альтернатив на основі їх соціально-економічних характеристик та відносної привабливості [8]. Найбільш розповсюдженими моделями даного класу є мультиноміальна логіт-модель, ієрархічна логіт-модель, мультиноміальна пробіт-модель та змішана логіт-модель. Розрахунок значень кореспонденцій на основі цих моделей здійснюється не безпосередньо, а заснований на ймовірності вибору пасажиром певного шляху пересування з усіх для нього можливих та прийнятних $[8,18,19]$. Моделі дискретного вибору у порівнянні з синтетичними дозволяють більш ретельно підійти до розрахунку кореспонденції, але оцінка їх точності дуже ускладнена потребою у реальній інформації про пересування.

До класу ймовірнісних моделей також можна віднести моделі множинної кореляції [20]. Сенс даних моделей полягає у встановленні факторів, що визначають виникнення потреб у пересуваннях, та їх впливу на формування пасажиропотоків через визначення коефіцієнтів у кореляційному рівнянні, що визначає кількість пересувань $D_{i j}$ :

$$
D_{i j}=a_{0}+a_{1} x_{1}+a_{2} x_{2}+\ldots+a_{p} x_{p}
$$

де $a_{p}$ - емпіричні коефіціснти, що встановлюються на основі натурних обстежень пересувань міського населення; $x_{p}$ - незалежні фактори, які визначають формування пасажиропотоків.

Окремо в межах ймовірнісного підходу можна виділити моделі безпосереднього попиту, які відрізняються від інших тим, що дозволяють одночасно вирішити три задачі моделювання потреб у 
пересуваннях - створення, розподіл і поділ. Загальна формула визначення кореспонденції згідно 3 даними моделями є мультиплікативною та записується як [8]

$$
D_{i j k}=\varphi\left(P_{i} P_{j}\right)^{\theta_{T 1}}\left(I_{i} I_{j}\right)^{\theta_{T 2}} \prod_{m}\left[\left(t_{i j}^{(y)}\right)^{\alpha_{r y}^{(1)}}\left(c_{i j}^{(y)}\right)^{\alpha_{r y}^{(2)}}\right],
$$

де $\varphi, \theta_{r 1}, \theta_{r 2}, \alpha_{r y}^{(1)}, \alpha_{r y}^{(2)}$ - параметри моделі; $P_{i}, P_{j}$ - чисельність населення в районах $i$ та $j ; I_{i}, I_{j}-$ рівень доходів населення в районах $i$ та $j ; t_{i j}^{(y)}$ - час поїздки між ТР $i$ та $j$ з використанням шляху пересування $y ; c_{i j}^{(y)}$ - вартість поїздки між ТР $i$ та $j$ з використанням шляху $y ; T-$ вид транспорту, яким можна користуватися при пересуванні між ТР $i$ та $j$.

Недоліком моделі (6) $є$ необхідність отримання досить великої кількості параметрів емпіричним шляхом. Слід також додати, що у [8] зазначається, що дана модель мало використовувалась при моделюванні міських пасажирських перевезень та в, більшій мірі, відносилась до міжміського сполучення.

Майже всім вищерозглянутим моделям розрахунку МПК властивий однозначний алгоритм розрахунку кореспонденцій та отримання в результаті точкової оцінки матриці. Кардинально інший підхід до визначення потреб населення у пересуваннях ГТ представлений в рамках інтервальної концепції визначення станів МПК, яку також можна віднести до ймовірнісних $[3,21,22]$. В рамках даної концепції приймається гіпотеза про те, що потреби у трудових пересуваннях носять випадковий характер і описуються не одною МПК, а їх сукупністю. Кожна матриця сукупності представляє собою один з можливих станів транспортного попиту. Діапазон їх зміни знаходиться в межах, котрим відповідають стани попиту з мінімальною та максимальною транспортною роботою, що виконується в процесі пересування пасажирів по місту. На відміну від всіх інших моделей визначення матриці кореспонденцій, концепція включає розрахунок оцінних показників, що визначають відмінності між матрицями сукупності. Одним з даних показників є різниця в транспортній роботі по реалізації МПК

$$
\Delta W=\sum_{i=1}^{N_{T P}} \sum_{j=1}^{N_{T P}} h_{i j} \cdot l_{i j}-\sum_{i=1}^{N_{T P}} \sum_{j=1}^{N_{T P}} h_{i j}^{\prime} \cdot l_{i j},
$$

де $h_{i j}$ - значення кореспонденції між ТР $i$ та $j$ у базовій МПК, пас.; $l_{i j}$ - відстань між районами $i$ та $j$, км; $h_{i j}^{\prime}$ - значення кореспонденції між ТР $i$ та $j$ у експериментальній МК, пас.

Іншим показником є відхилення значень кореспонденцій

$$
\Delta H=\sqrt{\sum_{i=1}^{N_{T P}} \sum_{j=1}^{N_{T P}}\left(h_{i j}-h_{i j}^{\prime}\right)^{2}} .
$$

3 використанням обраних показників (7), (8) можна оцінити межі інтервалу, в якому знаходяться достовірні МПК. Недоліком даної концепції $є$ широкий діапазон зміни станів матриць кореспонденцій, що робить оцінку транспортного попиту доволі «розмитою».

За результатами проведеного аналізу існуючих методів моделювання потреб населення в пересуваннях можна зробити висновок, що найбільш прийнятними для вирішення проблеми розрахунку МПК у малих містах є гравітаційна та ентропійна моделі, які при прийнятних витратах ресурсів дають адекватні результати.

Формулювання цілей роботи. Метою даної роботи є проведення оцінки точності результатів формування моделі попиту на пересування населення малого міста ГТ з використанням гравітаційної та ентропійної моделей. Порівняльною основою слугуватиме фактична МПК малого міста, яка отримана за результатами обстеження маршрутних кореспонденцій. В свою чергу, місткості ТР 3 відправлення та прибуття пасажирів отримані в ході цього ж обстеження $\epsilon$ основою для розрахунку пасажирських кореспонденцій за обраними синтетичними моделями. 
Основна частина. Результати аналізу методів формування моделей попиту на перевезення пасажирів свідчать про те, що найчастіше для формування МПК використовуються синтетичні моделі, а саме гравітаційна та ентропійна. Але слід зазначити, що на сьогодні для цих моделей відсутня загальноприйнята методика розрахунку, яка б забезпечувала виконання припущень про сталість місткостей ТР і обмежень за кількістю пасажирів, що вибувають з ТР і прибувають у них. Ліквідувати ці недоліки в рамках даного дослідження пропонується за рахунок проведення корегування значень розрахункових кореспонденцій, використовуючи «цикли», які будуються для перерозподілу обсягів між постачальниками та отримувачами при пошуку оптимального розв'язання транспортної задачі лінійного програмування $[21,23]$. При цьому за основу приймається стандартна методика розрахунку кореспонденцій за гравітаційною й ентропійною моделями 3 подальшим корегуванням отриманої матриці [21].

Отже, для досягнення поставленої мети роботи, а саме оцінювання точності основних синтетичних підходів щодо моделювання матриць кореспонденцій, дослідження необхідно проводити в наступній послідовності:

- розрахувати значення місткостей ТР 3 відправлення та прибуття пасажирів на основі фактичної матриці кореспонденцій (за фактичну матрицю кореспонденцій приймається МПК, яка сформована на основі проведеного таблично-візуального обстеження мережі маршрутів ГТ, методика проведення якого та методика формування фактичної МПК докладно наведені в [21]);

- сформувати варіанти синтетичних матриць кореспонденцій на основі відомих значень місткостей ТР з відправлення та прибуття пасажирів за допомогою гравітаційної та ентропійної моделей (рисунок 1);

- визначити показники оцінки точності (7), (8) для варіантів синтетичних матриць кореспонденцій та порівняти їх з оціночними показниками фактичної матриці.

Основними залежностями для визначення кореспонденцій в матрицях прийняті: для гравітаційної (1), а для ентропійної (3). Слід зазначити, що за функції спротиву, яка характеризуватиме складність сполучення, в даній роботі використовується відстань пересування пасажирів між ТР міста. Для обох синтетичних моделей використовуються найбільш розповсюджені ступені функцій спротиву, які мають прямопропорційний і зворотнопропорційний вплив на величину кореспонденцій (рисунок 1).

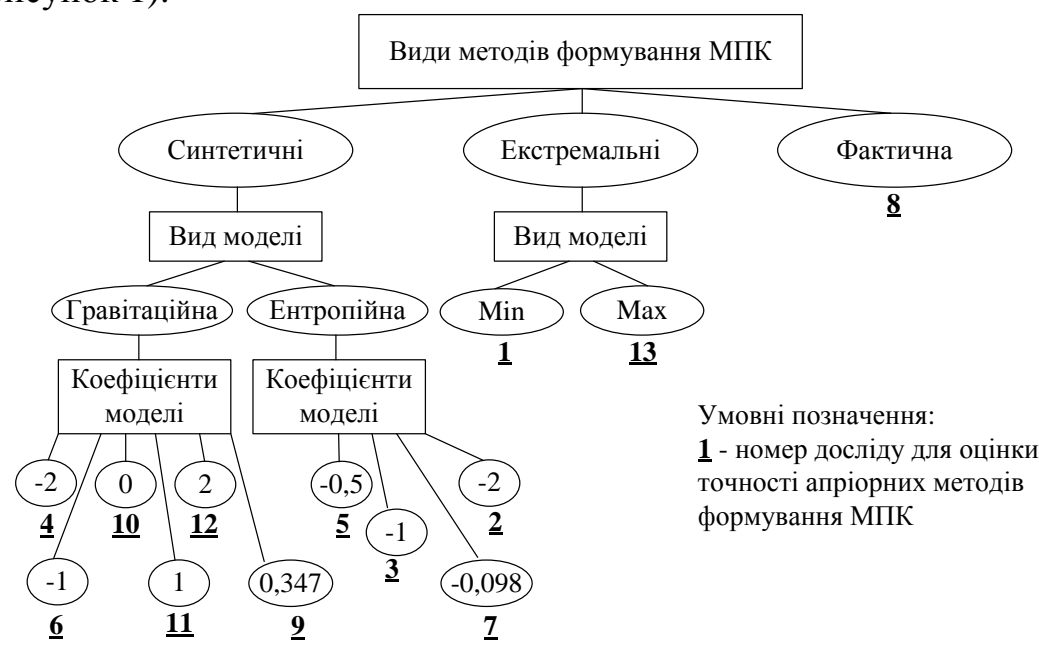

Рисунок 1 - Набір МПК, що моделюються для проведення оцінки за інтервальною концепцією

Також для обох моделей за допомогою вбудованого в Microsoft Excel пакета «Пошук рішення» [24] визначаються такі значення степенів функцій тяжіння, які забезпечують мінімальне відхилення транспортної роботи від фактичної матриці кореспонденцій.

Також необхідно зазначити, що для використання інтервальної концепції моделювання потреб населення в пересуваннях необхідно визначити граничні значення пошукового інтервалу, тобто необхідно сформувати так звані «екстремальні» варіанти матриць кореспонденцій, які мінімізують і максимізують показник транспортної роботи. Для формування таких матриць кореспонденцій можна використовувати прикладну кафедральну програму Mercs.exe. За вихідні дані використовуються значення місткостей ТР, а також матриці найкоротших відстаней між ТР. Після формування граничних варіантів МПК розраховуються значення оцінних показників (7), (8) для синтетичних МПК, які в подальшому порівнюються з оціночними показниками фактичної матриці. Повний набір 
МПК, що моделюються для проведення оцінки точності представлено на рисунку 1.

Слід також відзначити, що для отримання додаткової якісної оцінки транспортного обслуговування населення міста ГТ, в залежності від обраного варіанту моделі потреб пасажирів у пересуваннях обрано два критерію: середній час поїздки в транспортному засобі та середній час пересування маршрутною мережею, доцільність використання яких підтверджується [1]

За об’єкт проведення натурних обстежень обрано місто Куп'янськ Харківської області. Місто Куп'янськ, незважаючи на відносно невелику площу, має достатньо розвинену транспортну мережу, як для малих міст. Обслуговування населення, в основному, здійснюється міськими маршрутами, але певна частка містян обслуговується приміськими маршрутами. Для отримання результатів оцінки впливу варіанту МПК на ефективність функціонування маршрутної мережі міста за допомогою програмного продукту VISUM розроблено модель пасажирської маршрутної системи.

Отже, в результаті розрахунків сформовано 12 варіантів матриць кореспонденцій для міста Куп'янська. Наступним кроком досліджень $є$ перевірка точності розроблених варіантів матриць. Результати розрахунку обраних оцінювальних показників розрахункових матриць та показників ефективності обслуговування пасажирів ГТ для міста Куп'янська наведені в таблиці 1.

Таблиця 1 - Результати оцінювання точності розрахункових МПК для м. Куп'янська

\begin{tabular}{|c|c|c|c|c|c|c|}
\hline \multirow{2}{*}{$\begin{array}{c}\text { Номер } \\
\text { матриці }\end{array}$} & \multicolumn{2}{|c|}{$\begin{array}{c}\text { Різниця транспортної } \\
\text { роботи }\end{array}$} & \multicolumn{2}{c|}{$\begin{array}{c}\text { Різниця між } \\
\text { кореспонденціями }\end{array}$} & $\begin{array}{c}\text { Середній час } \\
\text { пересування } \\
\text { пасажира, хв. }\end{array}$ & $\begin{array}{c}\text { Середній } \\
\text { час поїздки, } \\
\text { хв. }\end{array}$ \\
\cline { 2 - 5 } & пас-км & $\%$ & пас. & $\%$ & 14,6 & 4,6 \\
\hline 1 & 1762,3 & 58,1 & 1262 & 166,3 & 15,7 & 5,0 \\
\hline 2 & 1615,7 & 53,3 & 1038 & 136,8 & 18,1 & 5,9 \\
\hline 3 & 1325,9 & 43,7 & 928 & 122,3 & 18,9 & 6,5 \\
\hline 4 & 1177 & 38,8 & 1038 & 136,8 & 20,8 & 7,1 \\
\hline 5 & 985,2 & 32,5 & 800 & 105,4 & 23,3 & 8,5 \\
\hline 6 & 558,5 & 18,4 & 796 & 104,9 & 26,6 & 10,5 \\
\hline 7 & 121,9 & 4,0 & 759 & 100,0 & 27,1 & 11,1 \\
\hline 8 & - & - & - & - & 28,4 & 11,6 \\
\hline 9 & 112,5 & 3,7 & 766 & 100,9 & 28,4 & 11,7 \\
\hline 10 & $-175,2$ & $-5,8$ & 772 & 101,7 & 29,7 & 13,1 \\
\hline 11 & $-510,5$ & $-16,8$ & 802 & 105,7 & 31,4 & 13,6 \\
\hline 12 & $-650,5$ & $-21,5$ & 832 & 109,6 & 32,8 & 15,2 \\
\hline 13 & $-942,3$ & $-31,1$ & 1228 & 161,8 & & \\
\hline
\end{tabular}

За результатами розрахунків оцінювальних показників встановлено, що найбільш близьким варіантом до фактичної матриці м. Куп'янська $\epsilon$ матриця, сформована за ентропійною моделлю зі ступенем функції спротиву «-0,098», відхилення транспортної роботи складає 4 \%, а показник різниці кореспонденцій - 100 \%. Слід зазначити, що навіть, маючи дуже близькі значення показника різниці транспортної роботи, розрахункові варіанти матриць кореспонденцій не можуть бути прийнятними для розробки заходів з підвищення ефективності транспортного обслуговування населення міста Куп'янська ГТ через значні відхилення показника різниці між кореспонденціями (в окремих випадках сягає 166 \%). Результати розрахунку показників ефективності обслуговування населення ГТ також свідчать, що найбільш близькою до фактичної МПК міста Куп'янська є матриця, сформована 3 використанням ентропійної моделі зі значенням ступеня функції спротиву, яка забезпечує мінімальне відхилення транспортної роботи від фактичної матриці кореспонденцій.

Отже, в результаті оцінювання можливостей розрахункових варіантів матриць кореспонденцій встановлено, що за допомогою синтетичних моделей можливо досягти незначних відхилень показника транспортної роботи сформованих МПК від фактичної матриці. Але, в той же час, за показником абсолютного відхилення значень кореспонденцій, навіть при цілеспрямованому калібруванні, досягти фактичних значень не вдалося. Це свідчить про необхідність додаткового визначення впливу розроблених варіантів МПК на ефективність пасажирських перевезень в малих містах. В якості оціночного показника можна обрати обсяг перевезення пасажирів на маршрутах.

Висновки. Результати оцінювання точності основних синтетичних моделей формування МПК свідчать про невідповідність розрахункових варіантів матриць кореспонденцій фактичним потребам населення міста в пересуваннях. Досягти повної відповідності результатів розрахунків реальному стану транспортного ринку не вдалося навіть при цілеспрямованому калібруванні моделей, що 
свідчить про недоцільність використання синтетичних моделей розрахунку матриць кореспонденцій для оцінювання потреб населення малих міст у пересуваннях.

Реалізація інтервальної концепції моделювання потреб населення в пересуваннях на прикладі малих міст дає занадто широкий полігон станів матриць кореспонденцій, що значно ускладнює процес транспортного планування в малих містах. Для зменшення меж пошукового діапазону найбільш перспективною, у порівнянні зі стандартним підходом, є методика формування МПК у малих містах, яка заснована на результатах обстеження пасажиропотоків на міських маршрутах табличним способом, що дозволяє істотно скоротити інтервал можливих станів матриць кореспонденцій.

1. ДБН Б.2.2-12:2018 Планування і забудова територій.

2. ДБН В.2.3-5:2017 Вулиці та дороги населених пунктів.

3. Горбачов П.Ф. Концепція формування систем маршрутного пасажирського транспорту в містах : дис. ... доктора техн. наук : 05.22.01 / Петро Федорович Горбачов. - Х., 2009. - 370 c.

4. Highway Capacity Manual 2000 : Transportation Research Board, National Research Council. - Washington, D.C., USA, 2000. -1134 p.

5. Доля В.К. Теоретические основы и методы организации маршрутных автобусных перевозок пассажиров в крупных городах [в 2 т] / В.К. Доля. - М., 1993. - 301 с.

6. Коцюк А.Я. Совершенствование автобусных маршрутных систем в крупных и крупнейших городах : автореф. дис. на соиск. ученой степени канд. техн. наук / А.Я. Коцюк. - Київ, 1990. -20 с.

7. Гуревич Г.А. Изучение транспортных потребностей - основа совершенствования работы пассажирского транспорта / Г.А. Гуревич, Г.И. Кузнецов, А.А. Михайлов // Автомобильный транспорт. Серия 4. Пасса-жирские перевозки автомобильным транспортом. Научно-технический реферативный сборник. -1980 . - № 2. - C. 1-5.

8. Ortuzar J.D. Modelling Transport / J.D. Ortuzar, L.G. Willumsen. - [Fourth Edition]. - Chichester: John Wiley \& Sons Ltd, 2011. -586 p.

9. Заблоцкий Г.А. Транспорт в городе / Г.А. Заблоцкий. - К.: Будівельник, 1986. -96 с.

10. Fratar T.J. Vehicular Trip Distribution by Successive Approximation / T.J. Fratar // Traffic Quarterly. - 1954. - №8. - p. $53-65$.

11. Брейдо Т.Е. Математическое моделирование транспортных сетей и оптимизация параметров их функционирования : автореф. дис. на соиск. ученой степени канд. техн. наук / Т.Е. Брейдо. - Горький, 1978. - 24 с.

12. Брайловский Н.О. Моделирование транспортных систем / Н.О. Брайловский, Б.И. Грановский. - М.: Транспорт, 1978. - 125 с.

13. Haynes E.K. Gravity and Spatial Interaction models / E.K. Haynes, A.S. Fotheringham // Sage-Publications. $-1984 .-$ p. 9-13.

14. Shahriar A.Z. An Integrated Urban Land Use and Transportation Demand Model Based on Lowry Linage / A.Z. Shahriar, A. Morteza // Journal of Applied Sciences. - 2008. - №8 (7). - p. 1197-1205.

15. Vries J.J. Alonso's General Theory of Movement: Advances in Spatial In-teraction Modeling / J.J. Vries, P. Nijkamp, P. Rietveld // Free University of Amsterdam, Department of Spatial Economics, Tinbergen Institute Discussion Paper. - 2000. - TI 2000-062/3.

16. Лозе Д. Моделирование транспортного предложения и спроса на транспорт для пассажирского и служебного транспорта, обзор теории моделирования : сборник докладов 7-й междунар. конф. "Организация и безопасность дорожного движения в крупных городах"/ Д. Лозе. - СПб.: СПб гос. архит.-строит. ун-т, 2006. - С. 170-186.

17. Вильсон А.Дж. Энтропийные методы моделирования сложных систем / А.Дж. Вилсон ; пер. с англ. Ю.А. Дубова ; [под. ред. Ю.С. Попкова]. - М. : Наука, 1978. - 248 с.

18. VISUM 10.0 User Manual [Електронний ресурc]. - 80 min / 700 MB. - 2007.

19. Preston J. Demand Forecasting for New Local Rail Stations and Services / J. Preston // Journal of Transport Economics and Policy. - 1991. - Vol. 25, № 2. - p. 183-202.

20. Ефремов И.С. Теория городских пассажирских перевозок : [учеб. пособие для вузов] / И.С. Ефремов, В.М. Кобозев, В.А. Юдин. - М.: Высшая Школа, 1980. - 535 с.

21. Любий С.В. Визначення попиту на пересування населення малих міст маршрутним пасажирським транспортом: дис. ... канд. техн. наук : 05.22.01 / Євген Володимирович Любий. - Харків, 2012. - 191 с.

22. Россолов А.В. Совершенствование интервальной концепции определения спроса на услуги пассажирского маршрутного транспорта в крупных городах: дис. ... канд. техн. наук : 05.22 .01 / Александр Викторович Россолов. Харьков, 2012. - 207 с.

23. Ляшенко И.Н. Линейное и нелинейное программирование : [учеб. пособ.] / И.Н. Ляшенко, Е.А. Карагодова, Н.В. Черникова, Н.З. Шор. - Издательское объединение "Вища Школа", К. : 1975. - 372 с.

24. Минько А.А. Статистический анализ в MS Excel / А.А. Минько - М.: Издательский дом «Вильямс», 2004. - 448 с.

\section{REFERENCES}

1. DBN B.2.2-12:2018 Planuvannia i zabudova terytorii.

2. DBN V.2.3-5:2017 Vulytsi ta dorohy naselenykh punktiv. thesis, 370

3. Horbachov, P.F. (2009). Kontseptsiia formuvannia system marshrutnoho pasazhyrskoho transportu v mistakh. Doctor's

4. Highway Capacity Manual 2000 (2000). Transportation Research Board, 1134.

5. Dolya, V.K. (1993). Teoreticheskie osnovy i metody organizatsii marshrutnykh avtobusnykh perevozok passazhirov v krupnykh gorodakh, 301. 
6. Kotsyuk, A.Ya. (1990). Sovershenstvovanie avtobusnykh marshrutnykh sistem v krupnykh i krupneyshikh gorodakh. Extended abstract of candidate's thesis, 20.

7. Gurevich, G.A., Kuznetsov, G.I., \& Mikhaylov, A.A. (1980). Izuchenie transportnykh potrebnostey - osnova sovershenstvovaniya raboty passazhirskogo transporta. Avtomobilnyy transport. Seriya 4. Passazhirskie perevozki avtomobilnym transportom. Nauchno-tekhnicheskiy referativnyy sbornik, $1-5$.

8. Ortuzar, J.D., \& Willumsen, L.G. (2011). Modelling Transport, 586 p.

9. Zablotskiy, G.A. (1986). Transport v gorode, 96.

10. Fratar, T.J. (1954). Vehicular Trip Distribution by Successive Approximation. Traffic Quarterly, 53-65.

11. Breydo, T.Ye. (1978). Matematicheskoe modelirovanie transportnykh setey i optimizatsiya parametrov ikh funktsionirovaniya. Extended abstract of candidate's thesis, 24.

12. Braylovskiy, N.O., \& Granovskiy, B.I. (1978). Modelirovanie transportnykh system, 125.

13. Haynes, E.K., \& Fotheringham, A.S. (1984). Gravity and Spatial Interaction models. Sage-Publications, 9-13.

14. Shahriar, A.Z., \& Morteza, A. (2008). An Integrated Urban Land Use and Transportation Demand Model Based on Lowry Linage. Journal of Applied Sciences. №8 (7), 1197-1205.

15. Vries, J.J., Nijkamp, P., \& Rietveldб P. (2000). Alonso's General Theory of Movement: Advances in Spatial Interaction Modeling. Tinbergen Institute Discussion Paper. TI 2000-062/3.

16. Loze, D. (2006). Modelirovanie transportnogo predlozheniya i sprosa na transport dlya passazhirskogo i sluzhebnogo transporta, obzor teorii modelirovaniya. Sbornik dokladov 7-y mezhdunar. konf. "Organizatsiya i bezopasnost dorozhnogo dvizheniya v krupnykh gorodakh", 170-186.

17. Vilson, A. Dzh. (1978). Entropiynye metody modelirovaniya slozhnykh sistem [per. s angl. Yu.A. Dubova], 248.

18. VISUM 10.0 (2007). User Manual [Elektronnyi resurs]. $80 \mathrm{~min} / 700 \mathrm{MB}$.

19. Preston, J. (1991). Demand Forecasting for New Local Rail Stations and Services. Journal of Transport Economics and Policy. Vol. 25, № 2, 183-202.

20. Yefremov, I.S., Kobozev, V.M., \& Yudin, V.A. (1980). Teoriya gorodskikh passazhirskikh perevozok, 535.

21. Liubyi, Ye.V. (2012). Vyznachennia popytu na peresuvannia naselennia malykh mist marshrutnym pasazhyrskym transportom. Candidate's thesis, 191.

22. Rossolov, A.V. (2012). Sovershenstvovanie intervalnoy kontseptsii opredeleniya sprosa na uslugi passazhirskogo marshrutnogo transporta v krupnykh gorodakh. Candidate's thesis, 207.

23. Lyashenko, I.N., Karagodova, Ye.A., Chernikova, N.V., \& Shor, N.Z. (1975). Lineynoe i nelineynoe programmirovanie, 372.

24. Minko, A.A. (2004). Statistical analysis in MS Exel, 448.

Любый Е.В., Колий А.С. Оценка точности синтетических моделей расчета пассажирских корреспонденций на примере малых городов

В работе рассмотрены вопросы оценки точности результатов формирования матрицы пассажирских корреспонденций с использованием гравитационной и энтропийной моделей на примере малых городов в рамках интервальной концепции моделирования потребностей населения городов в передвижениях. Основой для проведения такой оценки является наличие фактической матрицы корреспонденций, которая характеризует определенный расчетный период, и полученной путем проведения натурных наблюдений за работой общественного транспорта.

Ключевые слова: матрица пассажирских корреспонденций, малые города, оценка точности, синтетические модели, общественный транспорт, обследование пассажиропотоков.

Liubyi Ye.V., Kolii O.S. Estimation of accuracy of synthetic models of calculation of passenger correspondence on an example of small towns

The paper deals with the question of how to evaluate the accuracy of the results of the formation of OD-matrix using gravity and entropy models on the example of small towns in the framework of interval concept of modeling the needs of urban population in transportation. The basis for such an assessment is the availability of an actual OD-matrix, which characterizes a particular billing period, and which is based on the results of passenger traffic surveys on public transport.

Key words: OD-matrix, small towns, estimation of accuracy, synthetic models, public transport, passenger traffic survey.

ЛЮБИЙ Євген Володимирович, кандидат технічних наук, доцент кафедри транспортних систем i логістики, Харківський національний автомобільно-дорожній університет, e-mail: lion_khadi@ukr.net.

КОЛІЙ Олександр Сергійович, кандидат технічних наук, доцент кафедри транспортних систем і логістики, Харківський національний автомобільно-дорожній університет, e-mail: forgemest@gmail.com.

ЛЮБЫЙ Евгений Владимирович, кандидат технических наук, доцент кафедры транспортных систем и логистики, Харьковский национальный автомобильно-дорожный университет, e-mail: lionkhadi@ukr.net.

Колий Александр Сергеевич, кандидат технических наук, доцент кафедры транспортных систем и логистики, Харьковский национальный автомобильно-дорожный университет, e-mail: forgemest@gmail.com. 
LIUBYI Yevhen Volodymyrovych, Candidate of Technical Sciences, Associate Professor of Transport Systems and Logistics Department, Kharkiv National Automobile and Highway University, e-mail: lion_khadi@ukr.net.

KOLII Oleksandr Serhiiovych, Candidate of Technical Sciences, Associate Professor of Transport Systems and Logistics Department, Kharkiv National Automobile and Highway University, e-mail: forgemest@gmail.com.

Стаття надійшла в редакцію 26.04.2019 р. 